\title{
Bioactivity of quaternary glass prepared from bentonite clay
}

\author{
Luqman A. ADAMS ${ }^{a,}$, Enobong R. ESSIEN ${ }^{b}$ \\ ${ }^{a}$ Department of Chemistry, University of Lagos, Nigeria \\ ${ }^{b}$ Department of Chemical Sciences, Bells University of Technology, P.M.B 1015 Ota, Ogun, Nigeria
}

Received: July 27, 2015; Revised: September 15, 2015; Accepted: October 14, 2015

(C) The Author(s) 2016. This article is published with open access at Springerlink.com

\begin{abstract}
Alkoxysilane precursors are the most widely used silica source for sol-gel preparation of silicate-based bioactive glass. However, due to their high cost, alternative sources such as bentonite clay are desirable. In the present work, bentonite clay was reacted with sodium hydroxide $(\mathrm{NaOH})$ to extract sodium metasilicate $\left(\mathrm{Na}_{2} \mathrm{SiO}_{3}\right)$. The obtained $\mathrm{Na}_{2} \mathrm{SiO}_{3}$ was converted to gel which was then sintered at $950{ }^{\circ} \mathrm{C}$ for $3 \mathrm{~h}$ to give the bioactive glass in the quaternary composition $\mathrm{SiO}_{2}-\mathrm{NaO}-\mathrm{CaO}-$ $\mathrm{P}_{2} \mathrm{O}_{5}$. The resulting glass was incubated in simulated body fluid (SBF) for 0-7 days to evaluate the bioactivity. Furthermore, glass samples were characterized before and after SBF study by scanning electron microscopy (SEM), energy dispersive X-ray spectroscopy (EDX), X-ray diffraction (XRD), and Fourier transform infrared spectroscopy (FTIR). Results obtained showed the presence of $\mathrm{Na}_{2} \mathrm{Ca}_{2} \mathrm{Si}_{3} \mathrm{O}_{9}$ (combeite) crystal as the major crystalline phase and the formation of hydroxyapatite (HA) and hydroxycarbonated apatite (HCA) on the surface of the glass after immersion in SBF. The material showed potentials for application as scaffold in bone tissue repair.
\end{abstract}

Keywords: bentonite clay; bioactivity; alkoxysilane; hydroxyapatite (HA); bone repair

\section{Introduction}

The interest in bioactive glass has continued to soar particularly within the orthopaedic biomedical research community because of its ability to promote self-repair of damaged bones when used as temporary scaffold in vivo. The "gold standard" for bone treatment involves autograft and allograft transplantation. However, these methods have severe limitations and thus impose high cost on the health care system. The shortcomings associated with autograft include severe pain, morbidity of the harvested site, structural and anatomical problems, and high rate of resorption during healing [1,2]. Likewise, allograft may elicit

\footnotetext{
* Corresponding author.

E-mail: ladams@unilag.edu.ng
}

disease transmission and rejection, further compounded by shortage of donors $[3,4]$.

The use of bioactive glass for bone restoration represents a paradigm shift from replacement to regeneration through the use of synthetic bone grafts as positive effort to address the aforementioned drawbacks. The unique capability of bioactive glass over other bioceramics includes amongst others the ability to form hydroxyapatite (HA) on the surface when immersed in physiological environment $[5,6]$. This is beneficial because of the similarity in chemical composition of HA to bone and therefore facilitates the bonding between the material and bone [7]. Other significance of bioactive glass in physiological environment is its ability to elicit osteoblastic activity and improvement of cell adhesion [8]. Indeed, it has been reported that seven families of genes are up-regulated by the ionic dissolution products from 
bioactive glass [9].

Generally, sol-gel-derived glass, with its inherent mesoporosity, provides larger surface area and consequently more rapid degradation rate than melt-derived glass of similar composition $[10,11]$. Additionally, the sol-gel technology provides higher purity, homogeneity, and possibility of increasing the compositional range above $60 \mathrm{~mol} \%$ while maintaining bioactivity of the glass [12].

Recently, our research group embarked on the search for new silica-based materials as economic synthetic substitutes to the widely used alkoxysilane precursors such as tetraethyl orthosilicate (TEOS) and tetramethyl othosilicate (TMOS). Consequently, we have reported the synthesis of bioactive glass from sand and clay using the sol-gel technique $[13,14]$. However, in our use of bentonite clay as a novel starting material [14], we did not evaluate the bioactivity of the obtained bioceramic, and to the best of our knowledge, no previous work on the bioactivity of sol-gel-derived bioactive glass from bentonite clay has yet been reported. Therefore, herein we report the bioactivity of quaternary bioactive glass in the system $\mathrm{SiO}_{2}-\mathrm{Na}_{2} \mathrm{O}-\mathrm{CaO}-\mathrm{P}_{2} \mathrm{O}_{5}$ obtained from bentonite clay.

\section{Materials and methods}

\section{1 Materials}

The chemicals for the preparation of the bioactive glass included: bentonite clay $-(\mathrm{OH})_{4} \mathrm{Si}_{8} \mathrm{Al}_{4} \mathrm{O}_{20} \cdot n \mathrm{H}_{2} \mathrm{O}$ (Ijero-Ekiti, Nigeria), sodium hydroxide (SigmaAldrich, 99\%), nitric acid ( $\mathrm{HNO}_{3}$, Fluka, Germany), phosphoric acid $\left(\mathrm{H}_{3} \mathrm{PO}_{4}, \mathrm{BDH}\right.$ Laboratory, 98\%), sodium nitrate $\left(\mathrm{NaNO}_{3}\right.$, Sigma-Aldrich, 99\%), and calcium nitrate tetrahydrate $\left(\mathrm{Ca}\left(\mathrm{NO}_{3}\right)_{2} \cdot 4 \mathrm{H}_{2} \mathrm{O}\right.$, LOBA, 98\%). All chemicals were used as obtained without further purification.

\section{2 Methods}

To prepare the bioactive glass with composition $46.99 \mathrm{~mol} \% \mathrm{SiO}_{2}, 24.36 \mathrm{~mol} \% \mathrm{Na}_{2} \mathrm{O}, 25.50 \mathrm{~mol} \% \mathrm{CaO}$, and $3.15 \mathrm{~mol} \% \mathrm{P}_{2} \mathrm{O}_{5}$, sodium metasilicate $\left(\mathrm{Na}_{2} \mathrm{SiO}_{3}\right)$ was first extracted from bentonite clay as described previously [15]. In a typical sol-gel procedure, appropriate amount of the obtained $\mathrm{Na}_{2} \mathrm{SiO}_{3}$ was dissolved in deionized water to give a solution that was then added slowly to $1 \mathrm{M} \mathrm{HNO}_{3}$ in a beaker furnished with a magnetic stirrer under ambient temperature for $1 \mathrm{~h}$ to facilitate complete hydrolysis. Thereafter, $\mathrm{H}_{3} \mathrm{PO}_{4}$, $\mathrm{NaNO}_{3}$, and $\mathrm{Ca}\left(\mathrm{NO}_{3}\right)_{2} \cdot 4 \mathrm{H}_{2} \mathrm{O}$ were added under constant stirring to give a molar ratio $1: 10$ of each reagent to water in the sol. A reaction time of $45 \mathrm{~min}$ was allowed for each reagent before adding the next. After complete addition, the mixture was further stirred for $1 \mathrm{~h}$ to afford a gel. The resulting gel was aged at room temperature for 3 days, dried at $60{ }^{\circ} \mathrm{C}$ for $72 \mathrm{~h}$ and $130{ }^{\circ} \mathrm{C}$ for $42 \mathrm{~h}$, and stabilized at $700{ }^{\circ} \mathrm{C}$ for $2 \mathrm{~h}$. Finally, the material was sintered at $950{ }^{\circ} \mathrm{C}$ for $3 \mathrm{~h}$ for densification and strengthening of pore struts.

\section{3 Characterization}

The density of the bioactive glass $\rho_{\text {glass }}$ was calculated from the mass and dimensions of the sintered glass. The porosity $P$ was then obtained mathematically as follows:

$$
P=\left(1-\frac{\rho_{\text {glass }}}{\rho_{\mathrm{s}}}\right) \times 100
$$

where $\rho_{\mathrm{s}}=2.7 \mathrm{~g} / \mathrm{cm}^{3}$ is the theoretical density of $45 \mathrm{~S} 5$ Bioglass $^{\circledR}[16]$.

The microstructure, composition, and pore size distribution of the glass were evaluated in a Phenom Prox (Eindhoven, the Netherlands) scanning electron microscope (SEM) equiped with energy dispersive X-ray analyzer (EDX) before and after immersion in simulated body fluid (SBF). The sample was carbon-coated and observed at an accelerating voltage of $15 \mathrm{kV}$.

Samples were characterized using X-ray diffraction (XRD) analysis after sintering and after each immersion experiment in SBF with the aim of assessing the major phase present and the formation of hydroxyapatite (HA) crystal on samples' strut surface respectively. The samples were first ground to powder. Then $0.1 \mathrm{~g}$ of the powder was measured in a PANalytical Empyrean X-ray diffractometer using $\mathrm{Cu}$ $\mathrm{K} \alpha$ radiation source of wavelength $\lambda=0.154056 \mathrm{~nm}$ operated at $40 \mathrm{kV}$ and $40 \mathrm{~mA}$ to obtain the diffraction patterns in the $2 \theta$ range from $5^{\circ}$ to $90^{\circ}$.

Fourier transform infrared spectroscopy (FTIR, Shimadzu 8400S), with wavenumber range of $4000-400 \mathrm{~cm}^{-1}$ employing $\mathrm{KBr}$ pellets and operating in a reflectance mode with $4 \mathrm{~cm}^{-1}$ resolution, was employed to monitor the nature of bonds present in the as prepared samples. 


\section{4 In vitro bioactivity assessment in simulated body fluid}

Evaluation of bone bonding ability was carried out by the standard in vitro procedure [17]. The acellular simulated body fluid (SBF) was prepared using analytical reagent-grade chemicals $\mathrm{NaCl}$, $\mathrm{NaHCO}_{3}, \mathrm{KCl}, \mathrm{K}_{2} \mathrm{HPO}_{4} \cdot 3 \mathrm{H}_{2} \mathrm{O}, \mathrm{MgCl}_{2} \cdot 6 \mathrm{H}_{2} \mathrm{O}, \mathrm{CaCl}_{2}$, trishydroxymethyl aminomethane (Tris-buffer, $\left.\left(\mathrm{CH}_{2} \mathrm{OH}\right)_{3} \mathrm{CNH}_{2}\right)$, and $1 \mathrm{M} \quad \mathrm{HCl}$ with ion concentrations shown in Table 1. Samples were immersed in the SBF solution at a concentration of $0.01 \mathrm{~g} / \mathrm{mL}$ in clean plastic bottles, which were initially washed using $\mathrm{HCl}$ and deionized water. The bottles were placed inside a thermostated incubator at a temperature of $36.5^{\circ} \mathrm{C}$ and an initial $\mathrm{pH}$ of 7.4. The SBF solutions were not refreshed throughout the period of immersion to allow for measurement of $\mathrm{pH}$ of the solution at different intervals between 0 and $120 \mathrm{~h}$ duration using a $\mathrm{pH}$ meter (Hanna, HI96107) previously calibrated with buffer solutions of $\mathrm{pH}=4.0$, 7.0, and 9.0. The samples were extracted from the SBF solution after 3 and 7 days. The extracted samples were rinsed with deionized water and left to dry at ambient temperature in a desiccator. The formation of apatite layer on the glass surface was monitored by SEM, EDX, XRD, and FTIR.

\section{Results}

\section{1 Changes in morphology}

The morphology of the glass before and after immersion in SBF is shown in Fig. 1. As observed in Fig. 1(a), before immersion, the glass presents almost uniform porous surface containing mostly cuboid-shaped glass architecture well distributed throughout the material. The porosity of the glass obtained by applying Eq. (1) is $82 \%$. After immersion in SBF for 3 days, the glass morphology changes to fine grain-sized particles, most of which are agglomerated as shown in Fig. 1(b). The EDX spectrum during this period of immersion shows a decrease in the concentrations of $\mathrm{Na}, \mathrm{Si}$, and $\mathrm{Ca}$ but an

Table 1 Ion concentration in human plasma in comparison with $\mathrm{SBF}$ (unit: $\mathrm{mM}$ )

\begin{tabular}{ccccccccc}
\hline Ion & $\mathrm{Na}^{+}$ & $\mathrm{K}^{+}$ & $\mathrm{Mg}^{2+}$ & $\mathrm{Ca}^{2+}$ & $\mathrm{Cl}^{-}$ & $\mathrm{HCO}_{3}^{-}$ & $\mathrm{HPO}_{4}^{2-}$ & $\mathrm{SO}_{4}^{2-}$ \\
\hline $\begin{array}{c}\text { SBF } \\
142.0\end{array}$ & 5.0 & 1.5 & 2.5 & 147.8 & 4.2 & 1.0 & 0.5 \\
$\begin{array}{c}\text { Human } \\
\text { plasma }\end{array}$ & 142.0 & 5.0 & 1.5 & 2.5 & 103.0 & 27.0 & 1.0 & 0.5 \\
\hline
\end{tabular}

increase in P. These changes can be attributed to the formation of $\mathrm{HA}$ on the surface of the glass. After immersion for 7 days in SBF (Fig. 1(c)), the micrograph shows dense clusters of HA particles, which also appear coarse. Accordingly, the EDX spectrum records low detection of Si due to increase in population of apatite on the glass surface, while the concentrations of $\mathrm{Ca}$ and $\mathrm{P}$ increase. Furthermore, a small carbon peak becomes evident indicating the formation of crystalline hydroxycarbonated apatite (HCA).
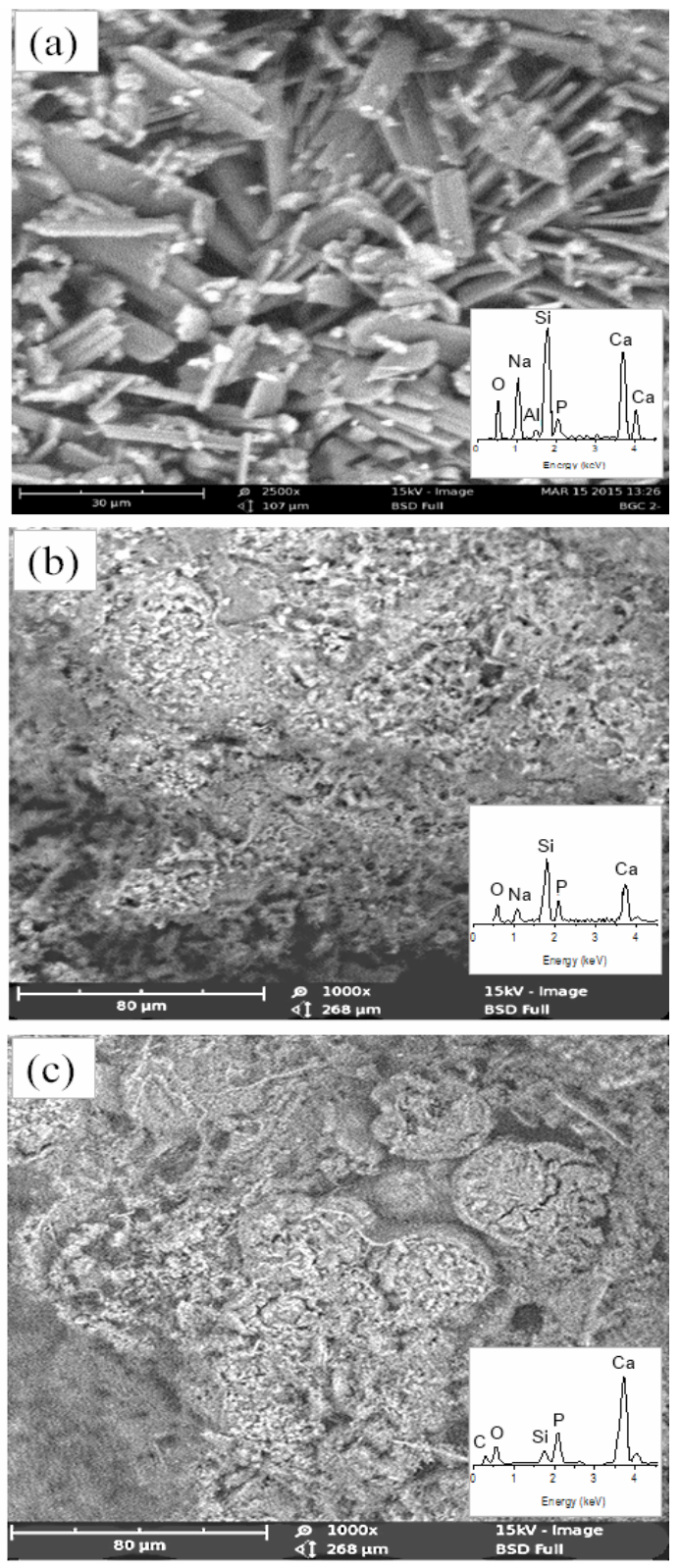

Fig. 1 SEM micrographs with EDX insets of the bioactive glass showing the growth of apatite: (a) as sintered, (b) after soaking in SBF for 3 days, and (c) after soaking in SBF for 7 days. 


\section{2 Diffraction patterns}

The XRD investigation of the glass samples after annealing at $950{ }^{\circ} \mathrm{C}$ for $3 \mathrm{~h}$ reveals the presence of major peaks of combeite $\left(\mathrm{Na}_{2} \mathrm{Ca}_{2} \mathrm{Si}_{3} \mathrm{O}_{9}\right)$ crystal usually formed from devitrification of quaternary system of $\mathrm{SiO}_{2}-\mathrm{Na}_{2} \mathrm{O}-\mathrm{CaO}-\mathrm{P}_{2} \mathrm{O}_{5}$ bioactive glass $[18,19]$ as shown in Fig. 2(a). Both the angular location and intensity of the peaks match the standard PDF $\# 22.1455$. As seen, it is obvious that the glass does not fully crystallize judging by the low intensities of the $\mathrm{Na}_{2} \mathrm{Ca}_{2} \mathrm{Si}_{3} \mathrm{O}_{9}$ peaks at locations other than the one at $2 \theta \approx 30^{\circ}$. Even before immersion in SBF, a peak identified as apatite is clearly visible at $2 \theta \approx 32^{\circ}$. This phenomenon has been attributed to the aqueous environment of the sol-gel process which favours the precipitation of HA from the amorphous structure of silica-based bioactive glass [20].

After immersion in SBF, the intensity of the $\mathrm{Na}_{2} \mathrm{Ca}_{2} \mathrm{Si}_{3} \mathrm{O}_{9}$ peaks decreases gradually as shown in Figs. 2(a)-2(c). The gradual decrease is an indication that the material could have controlled degradation rate in physiological fluids, and hence is able to act as temporary scaffold prior to complete integration of the damaged site, as a major requirement of an ideal scaffold for bone repair [21]. Apatite peaks increase as immersion duration is prolonged. All apatite positions are corroborated by those in the standard PDF JCPDS \#9-0432.

\section{3 Assessment of bonds}

The FTIR spectrum of the pristine bioactive glass is shown in Fig. 3(a). As observed, there are prominent peaks at $3462,1684,1458,1005,850,602$, and

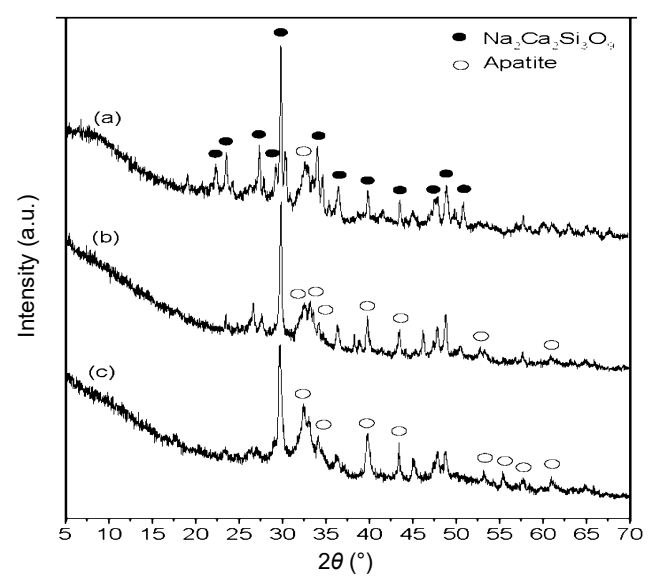

Fig. 2 XRD spectra of the bioactive glass during the period of incubation for (a) 0 day, (b) 3 days, and (c) 7 days showing phases present.
$457 \mathrm{~cm}^{-1}$. The broad band between 3300 and $3800 \mathrm{~cm}^{-1}$ centred at $3462 \mathrm{~cm}^{-1}$ is due to $\mathrm{OH}$ groups in the material, which is further confirmed by the presence of water absorbed band around $1684 \mathrm{~cm}^{-1}$. The band at $1458 \mathrm{~cm}^{-1}$ is representative of the absorption of carbonate group $\left(v_{3}\right)$, while the sharp peak at $1005 \mathrm{~cm}^{-1}$ is associated with $\mathrm{Si}-\mathrm{O}-\mathrm{Si}$ vibrational modes [22]. The peak at $850 \mathrm{~cm}^{-1}$ is synonymous with $\mathrm{C}-\mathrm{O}$ stretching vibration [22], which may be due to adsorption of atmospheric $\mathrm{CO}_{2}$ during the processing stage of the glass. There is an intense peak at $602 \mathrm{~cm}^{-1}$ which is assigned to $\mathrm{P}-\mathrm{O}$ bending mode in crystalline calcium phosphate, and another small peak at $457 \mathrm{~cm}^{-1}$ is attributed to $\mathrm{Si}-\mathrm{O}-\mathrm{Si}$ bending vibrations. After immersion for 3 days (Fig. 3(b)), the peak at $1458 \mathrm{~cm}^{-1}$ becomes broader and splits into two modes at 1476 and $1424 \mathrm{~cm}^{-1}$, and similarly the peak at $602 \mathrm{~cm}^{-1}$ develops into two modes at 604 and $569 \mathrm{~cm}^{-1}$. These are characteristics of apatite crystalline phase [23], signalling the incorporation of $\mathrm{CO}_{3}^{2-}$ from the SBF solution into $\mathrm{HA}$ on the glass surface to form HCA. While after 7-day immersion in SBF (Fig. 3(c)), the twin peaks at 604 and $569 \mathrm{~cm}^{-1}$ become more intense due to increase in density of HCA on the surface of the glass, thus explaining the appearance of the small carbon peak observed in the EDX spectrum (Fig. 1(c) inset).

\section{4 Reactivity in SBF}

Figure 4 shows the $\mathrm{pH}$ change of the glass in SBF for the first $120 \mathrm{~h}$, which is in agreement with the reaction sequence of bioactive glass in biological fluids [5]. As observed, there is fast release of alkali and alkaline

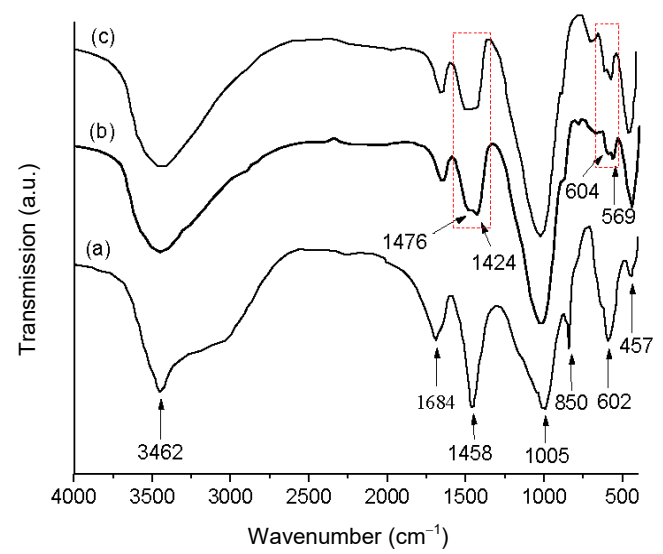

Fig. 3 FTIR spectra of the glass immersed in SBF for (a) 0 day, (b) 3 days, and (c) 7 days. Similar absorption patterns are marked in red doted rectangle. 
earth ions $\left(\mathrm{Na}^{+}\right.$and $\left.\mathrm{Ca}^{2+}\right)$ from the glass into SBF solution during the first $4 \mathrm{~h}$ leading to an increase in $\mathrm{pH}$ of the solution from the initial 7.4 to 10.0 . The first stage of the reaction involves ion-exchange between $\mathrm{Na}^{+}$and $\mathrm{Ca}^{2+}$ of the glass with $\mathrm{H}^{+}$or $\mathrm{H}_{3} \mathrm{O}^{+}$of the solution [18]:

$-\mathrm{Si}_{\mathrm{j}} \mathrm{O}^{-} \mathrm{Na}^{+}+\mathrm{H}^{+} \longrightarrow-\mathrm{Si}_{\mathrm{j}}-\mathrm{OH}+\mathrm{Na}^{+}(\mathrm{aq})$

After $4 \mathrm{~h}$, the $\mathrm{pH}$ increases slowly until $48 \mathrm{~h}$ because part of the released $\mathrm{Ca}^{2+}$ from the glass is used to form CaO- $\mathrm{P}_{2} \mathrm{O}_{5}$, thus decreasing the release rate as shown in Fig. 4. As immersion duration reaches $96 \mathrm{~h}$, the $\mathrm{pH}$ increase slows further as more $\mathrm{Ca}^{2+}$ is withdrawn from the SBF solution to develop HCA layer on the surface of the glass. Finally, the $\mathrm{pH}$ reaches a saturated value of 11.7 after $96 \mathrm{~h}$ without increasing any further due to crystallization of HCA.

\section{Discussion}

\section{1 Composition}

Bentonite clay, a naturally occurring sedimentary clay with the chemical formula $(\mathrm{OH})_{4} \mathrm{Si}_{8} \mathrm{Al}_{4} \mathrm{O}_{20} \cdot n \mathrm{H}_{2} \mathrm{O}$, has a 3-layer structure displaying one aluminium oxide sheet sandwiched by two silicon oxide sheets. The arrangement is such that $\mathrm{Mg}^{2+}$ ions may substitute for $\mathrm{Al}^{3+}$ ions leaving a net negative charge on the sheets [14]. The clay is reacted with $\mathrm{NaOH}$ to extract the $\mathrm{Si}^{4+}$ ions from the sheets to form $\mathrm{Na}_{2} \mathrm{SiO}_{3}$ as filtrate and $\mathrm{Al}(\mathrm{OH})_{3}$ as residue as shown in a previous reaction scheme [14]. The obtained $\mathrm{Na}_{2} \mathrm{SiO}_{3}$ then serves as precursor for $\mathrm{SiO}_{2}$ and $\mathrm{Na}_{2} \mathrm{O}$ for preparing the glass. The EDX result of the sintered glass as shown in Fig. 5 confirms the presence of all the elements in their appropriate ratios as prepared. Additionally, a residual

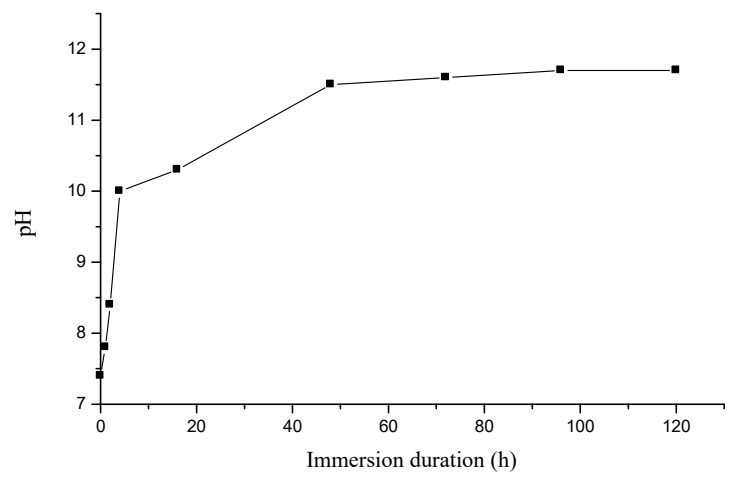

Fig. $4 \mathrm{pH}$ change of the glass during immersion in SBF for $120 \mathrm{~h}$.

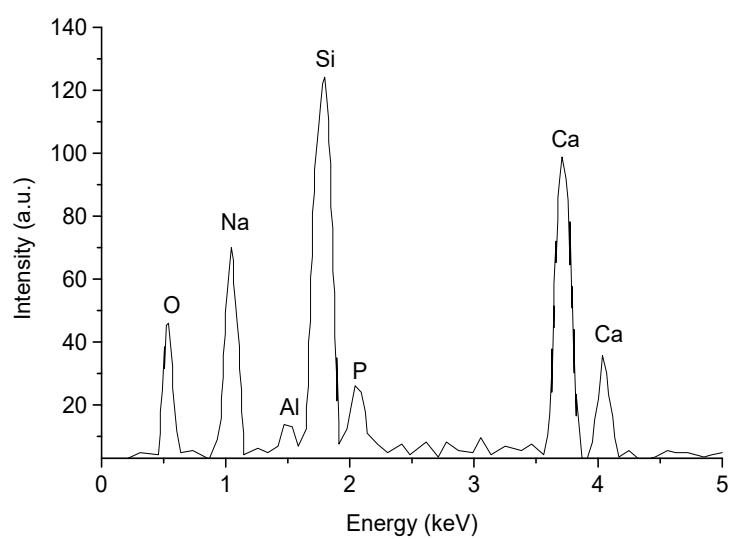

Fig. 5 Elemental composition of the parent glass as measured by EDX.

peak of $\mathrm{Al}$ observed in the spectrum may be due to incomplete removal of $\mathrm{Al}(\mathrm{OH})_{3}$ from the $\mathrm{Na}_{2} \mathrm{SiO}_{3}$ filtrate during the extraction stage. Hence a more efficient filtration method, such as vacuum filtration, may be necessary. Apart from bentonite clay, kaolinite clay $\left(\mathrm{Al}_{2} \mathrm{Si}_{2} \mathrm{O}_{5}(\mathrm{OH})_{4}\right)$ could serve as another cheap alternative source of silica.

\section{2 Microstructure}

The glass exhibits sub-micron pore diameter of mean value $2.54 \mu \mathrm{m}$ (Fig. 6(a)), while the average pore area is $0.29 \mu \mathrm{m}^{2}$ (Fig. 6(b)). This is expected as clay particles themselves have dimensions on nanoscale [24,25], thus arrangement of these particles leads to evolution of large surface area associated with sub-micron pore structure as observed in Fig. 6. The microstructure of the glass as well as its porosity of $82 \%$ are crucial textural parameters for enhanced cell adhesion, vascularisation, infiltration, and osteointegration on the glass material [26-31].

\section{4. $3 \mathrm{Na}_{2} \mathrm{Ca}_{2} \mathrm{Si}_{3} \mathrm{O}_{9}$ crystalline phase}

The $\mathrm{Na}_{2} \mathrm{Ca}_{2} \mathrm{Si}_{3} \mathrm{O}_{9}$ crystal detected in the XRD spectrum (Fig. 2) is the major crystalline phase, and displays cuboidal architecture as seen in the SEM micrograph shown in Fig. 1(a). During sintering, $\mathrm{Na}_{2} \mathrm{O}$, $\mathrm{CaO}$, and $\mathrm{SiO}_{2}$ present in the composition react to form $\mathrm{Na}_{2} \mathrm{Ca}_{2} \mathrm{Si}_{3} \mathrm{O}_{9}$. Mechanical strength is a significant factor in the choice of an ideal scaffold to serve as temporary support for new bone growth [31]. While there have been concerns about the biodegradability of crystalline $\mathrm{Na}_{2} \mathrm{Ca}_{2} \mathrm{Si}_{3} \mathrm{O}_{9}$, some authors have reported different scaffold designs and synthetic route optimization to improve degradation behaviour of $\mathrm{Na}_{2} \mathrm{Ca}_{2} \mathrm{Si}_{3} \mathrm{O}_{9}$ in physiological fluids [31-33]. In the 


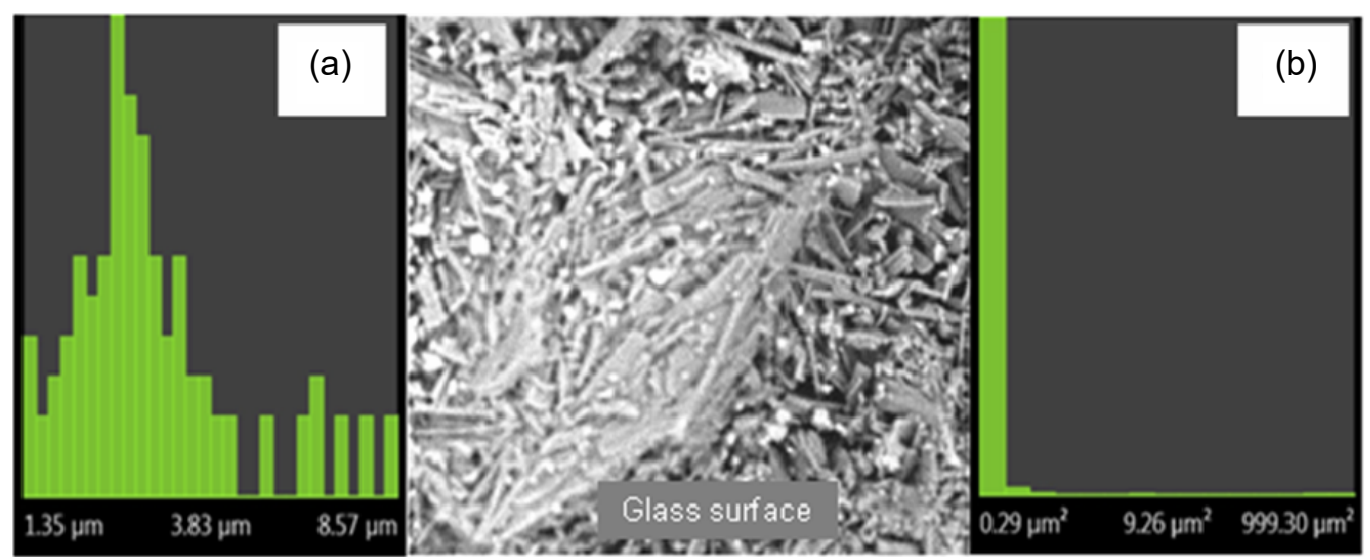

Fig. 6 Fibrematrics of the glass after sintering showing (a) pore size distribution and (b) average pore area of the glass surface (middle) as determined by SEM.

present work, to ensure partial crystallization, the sintering protocol was set at $950{ }^{\circ} \mathrm{C}$ for $3 \mathrm{~h}$. The gradual transformation of the glass from crystalline to amorphous after soaking in SBF for 7 days indicates biodegradability [26,34-38].

\section{4 pH change in SBF}

The steep rise in $\mathrm{pH}$ during the first $4 \mathrm{~h}$ of soaking in SBF indicates high reactivity of the glass. The large surface area conferred on the glass by well distributed particles and sub-micron-sized pores presents optimal sites for ion-exchange reaction to occur. This phenomenon explains why apatite nucleation occurs at a shorter time, even without immersion in SBF, as observed in the spectra for XRD and FTIR in Fig. 2(a) and Fig. 3(a) respectively. At the end of $120 \mathrm{~h}$ (5 days), the $\mathrm{pH}$ reaches a value of 11.7 from the initial 7.4 during which apatite colony increases on the surface of the glass as evident by the low detection of Si recorded by EDX shown in Fig. 1(a). The basis of bonding property of bioactive glass has been anchored on the chemical reactivity in physiological body fluids (in vitro and in vivo), which leads to the formation of HCA layer to which bone can bond.

\section{Conclusions}

The highly bioactive glass in quaternary composition has been prepared starting with bentonite clay as silica source instead of conventional alkoxysilane precursors. The large surface area and micron-sized pore structure obtained through the sol-gel processing method were key in accelerating the reactivity of the glass in SBF to form apatite. The crystalline $\mathrm{Na}_{2} \mathrm{Ca}_{2} \mathrm{Si}_{3} \mathrm{O}_{9}$ formed from sintering the glass is important in reinforcing the strength of the material during application as scaffold in bone repair. Interestingly, the crystalline phase did not hinder the biodegradability of the glass in SBF. With continuing efforts geared towards cost effective design of scaffolds for optimal bioactivity, bentonite clay may be a potential cheap raw material for the preparation of bioactive glass.

\section{Acknowledgements}

The authors are thankful to Mr. Femi Igbari of the College of NanoScience and Technology, Soochow University, China, for his assistance with the EDX and XRD characterisations as well as Mr. Isa Yakubu of Ahmadu Bello University Zaria for the SEM analysis.

\section{References}

[1] Lee S-C, Chen J-F, Wu C-T, et al. In situ local autograft for instrumented lower lumbar or lumbosacral posterolateral fusion. J Clin Neurosci 2009, 16: 37-43.

[2] Damien CJ, Parsons JP. Bone graft and bone substitutes: A review of current technology and applications. J Appl Biomater 1991, 2: 187-208.

[3] Calori GM, Mazza E, Colombo M, et al. The use of bone-graft substitutes in large bone defects: Any specific needs? Injury 2011, 42: S56-S63.

[4] Rose FRAJ, Oreffo ROC. Bone tissue engineering: Hope vs hype. Biochem Bioph Res Co 2002, 292: 1-7.

[5] Hench LL. Bioceramics. J Am Ceram Soc 1998, 81: 1705-1728.

[6] Rahaman MN, Day DE, Bal BS, et al. Bioactive glass in tissue engineering. Acta Biomater 2011, 7: 2355-2373.

[7] Oonishi H, Hench LL, Wilson J, et al. Comparative bone growth behaviour in granules of bioceramic materials of 
various sizes. J Biomed Mater Res 1999, 44: 31-43.

[8] Olmo N, Martin AI, Salinas AJ, et al. Bioactive sol-gel glasses with and without a hydroxycarbonate apatite layer as substrates for osteoblast cell adhesion and proliferation. Biomaterials 2003, 24: 3383-3393.

[9] Jell G, Stevens MM. Gene activation by bioactive glasses. J Mater Sci: Mater M 2006, 17: 997-1002.

[10] Pereira MM, Jones JR, Orefice RL, et al. Preparation of bioactive glass-polyvinyl alcohol hybrid foams by the sol-gel method. J Mater Sci: Mater M 2005, 16: $1045-1050$.

[11] Wu C, Luo Y, Cuniberti G, et al. Three-dimensional printing of hierarchical and tough mesoporous bioactive glass scaffolds with a controllable pore architecture, excellent mechanical strength and mineralization ability. Acta Biomater 2011, 7: 2644-2650.

[12] Fardad MA. Catalysis and structure of $\mathrm{SiO}_{2}$ sol-gel films. J Mater Sci 2000, 35: 1835-1841.

[13] Essien ER, Adams LA, Shaibu, RO, et al. Economic route to sodium-containing silicate bioactive glass scaffold. Open Journal of Regenerative Medicine 2012, 1: 33-40.

[14] Essien ER, Adams LA, Shaibu, RO, et al. Sol-gel bioceramic material from bentonite clay. Journal of Biomedical Science and Engineering 2013, 6: 258-264.

[15] Essien ER, Olaniyi OA, Adams LA, et al. Sol-gel-derived porous silica: Economic synthesis and characterization. Journal of Minerals and Materials Characterization and Engineering 2012, 11: 976-981.

[16] Cao W, Hench LL. Bioactive materials. Ceram Int 1996, 22: 493-507.

[17] Kokubo T, Takadama H. How useful is SBF in predicting in vivo bone bioactivity? Biomaterials 2006, 27: 2907-2915.

[18] Clupper DC, Mecholsky Jr. JJ, LaTorre GP, et al. Sintering temperature effects on the in vitro bioactive response of tape cast and sintered bioactive glass-ceramic in Tris buffer. J Biomed Mater Res 2001, 57: 532-540.

[19] Clupper DC, Mecholsky Jr. JJ, LaTorre GP, et al. Bioactivity of tape cast and sintered bioactive glass-ceramic in simulated body fluid. Biomaterials 2002, 23: 2599-2606.

[20] Chen Q-Z, Li Y, Jin L-Y, et al. A new sol-gel process for producing $\mathrm{Na}_{2} \mathrm{O}$-containing bioactive glass ceramics. Acta Biomater 2010, 6: 4143-4153.

[21] Gerhardt L-C, Boccaccini AR. Bioactive glass and glass-ceramic scaffolds for bone tissue engineering. Materials 2010, 3: 3867-3910.

[22] Peitl O, Zanotto ED, Hench LL. Highly bioactive $\mathrm{P}_{2} \mathrm{O}_{5}-\mathrm{Na}_{2} \mathrm{O}-\mathrm{CaO}-\mathrm{SiO}_{2}$ glass-ceramics. J Non-Cryst Solids 2001, 292: 115-126.

[23] Oliveira JM, Correia RN, Fernandes MH. Effects of Si speciation on the in vitro bioactivity of glasses. Biomaterials 2002, 23: 371-379.
[24] Alexandre M, Dubois P. Polymer-layered silicate nanocomposites: Preparation, properties and uses of a new class of materials. Mat Sci Eng R 2000, 28: 1-63.

[25] Katti KS, Katti DR. Relatioship of swelling and swelling pressure on silica-water interactions in montmorillonite. Langmuir 2006, 22: 532-537.

[26] Rezwan K, Chen QZ, Blaker JJ, et al. Biodegradable and bioactive porous polymer/inorganic composite scaffolds for bone tissue engineering. Biomaterials 2006, 27: 3413-3431.

[27] Vitale-Brovarone C, Miola M, Balagna C, et al. 3D-glass-ceramic scaffolds with antibacterial properties for bone grafting. Chem Eng J 2008, 137: 129-136.

[28] Karageorgiou V, Kaplan D. Porosity of 3D biomaterial scaffolds and osteogenesis. Biomaterials 2005, 26: 5474-5491.

[29] Smith IO, Ren F, Baumann MJ, et al. Confocal laser scanning microscopy as a tool for imaging cancellous bone. J Biomed Mater Res B 2006, 79: 185-192.

[30] Woodard JR, Hilldore AJ, Lan SK, et al. The mechanical properties and osteoconductivity of hydroxyapatite bone scaffolds with multi-scale porosity. Biomaterials 2007, 28: 45-54.

[31] Vitale-Brovarone C, Baino F, Verné E. High strength bioactive glass-ceramic scaffolds for bone regeneration. J Mater Sci: Mater M 2009, 20: 643-653.

[32] Du R, Chang J. Preparation and characterization of bioactive sol-gel-derived $\mathrm{Na}_{2} \mathrm{Ca}_{2} \mathrm{Si}_{3} \mathrm{O}_{9}$. J Mater Sci: Mater M 2004, 15: 1285-1289.

[33] Filho OP, LaTorre GP, Hench LL. Effect of crystallization on apatite-layer formation of bioactive glass $45 \mathrm{~S} 5$. J Biomed Mater Res 1996, 30: 509-514.

[34] Chen QZ, Thompson ID, Boccaccini AR. 45S5 Bioglasss ${ }^{\circledR}$-derived glass-ceramic scaffolds for bone tissue engineering. Biomaterials 2006, 27: 2414-2425.

[35] Hench LL, Polak JM. Third-generation biomedical materials. Science 2002, 295: 1014-1017.

[36] Hench LL. The story of Bioglass ${ }^{\circledR}$. J Mater Sci: Mater M 2006, 17: 967-978.

[37] Hench LL Bioceramics: From concept to clinic. $J$ Am Ceram Soc 1991, 74: 1487-1510.

[38] Hench LL, Andersson Ö. Bioactive glasses. In: An Introduction to Bioceramics. Hench LL, Wilson J, Eds. Singapore: World Scientific Publishing, 1993: 41-62.

Open Access The articles published in this journal are distributed under the terms of the Creative Commons Attribution 4.0 International License (http://creativecommons.org/licenses/ by/4.0/), which permits unrestricted use, distribution, and reproduction in any medium, provided you give appropriate credit to the original author(s) and the source, provide a link to the Creative Commons license, and indicate if changes were made. 